\title{
Introducing Investment Promotion: A Marketing Approach to Attracting Foreign Direct Investment
}

\author{
Bamituni E. Abamu ${ }^{1}$ \\ ${ }^{1}$ Faculty of Economics, University of Gdańsk, Sopot, Poland \\ Correspondence: Bamituni E. Abamu, Faculty of Economics, University of Gdańsk, Armii Krajowej 119, 81-824, \\ Sopot, Poland. E-mail: bamituniabamu@gmail.com
}

Received: October 23, 2019 Accepted: November 18, 2019 Online Published: November 23, 2019

doi:10.5539/ijms.v11n4p91 URL: https://doi.org/10.5539/ijms.v11n4p91

\begin{abstract}
This paper introduces the concept of investment promotion, a form of marketing used by national governments to attract foreign investments into their country. While it is not a new concept, it barely makes it to academic literature. The paper brings investment promotion to the forefront for the purpose of creating a research interest in this topic and also contributes to the development of literature. It attempts to integrate investment promotion activities into already established marketing models and frameworks and set a marketing research agenda on the topic. Since attracting foreign investment is a policy and country situation issue, this paper will support and serve as a reference for governments as they design foreign investment policies and improve the attractiveness of their country as an investment destination using marketing tools. The paper first discusses the influence of marketing on investment promotion and how investors should be viewed as consumers who have needs to be satisfied. Various frameworks and concepts like the consumer decision-making process, market segmentation and marketing communications mix are discussed to show how they can be applied in investment promotion. The application of marketing concepts and theories has been beneficial in the business world, and this paper argues that there are potential benefits for countries who decide to apply the same concept and theories to attract investors.
\end{abstract}

Keywords: investment promotion, marketing communication, decision making process, segmentation, industrial marketing, foreign direct investment

\section{Introduction}

In the business world, for a company to be successful, it is important that potential customers are aware of its product or service. Even when the company is well known within the market it operates, there is still a need for awareness regarding special offers and especially, the introduction of new products and services. Marketing as a practice has always been the purview of business organizations. However, it is becoming a mainstay for governments and its institutions in their bid to attract foreign investments into their country. Foreign direct investment is important to the economic development of a country, and policy makers have recognized the benefits FDI brings to the economy which includes jobs, new technology, managerial knowledge, technical skills and the opening of new foreign markets (Aitken \& Harrison, 1999; Hill, 2000; Harding \& Javorcik, 2011). This has led to increased competition among countries and regions to attract the inflow of FDI, forcing national and regional governments to adopt marketing practices. This marketing practice is known as investment promotion.

There have been little to no academic literature and research papers on investment promotion and the use of marketing models have not been fully explored. Sources for investment promotion literature can mainly be found in policy papers compiled by governmental and international organizations such as the United Nations, World Bank, Organization for Economic Co-operation and Development (OECD), Food and Agricultural Organization (FAO), and the World Association of Investment Promotion Agencies (WAIPA). One such policy paper publication is the Foreign Investment Advisory Service (FIAS) published by the World Bank. Other sources of literature come from private organizations involved in consultancy service business.

This paper discusses the concept of investment promotion and the marketing models that have been used in attracting FDI. It also aims to contribute to the body of literature in this field. 


\section{Influence of Marketing}

To understand how marketing strategies and frameworks are applied in the attraction of foreign investments, it is necessary to understand the concept of marketing by defining its meaning and role. Several definitions of marketing have been made by authors and professional bodies. However, most seem to identify marketing as a "process" and an "exchange of value". One popular definition is that of the Chartered Institute of Marketing (CIM) which defines marketing as "the management process responsible for identifying, anticipating and satisfying customer requirements profitably". Kotler, Armstrong, Saunders and Wong (2001) defines marketing as "a social and managerial process by which individuals and groups obtain what they need and want through creating and exchanging products and value with others". Varey (2001) provides a working knowledge definition stating it is concerned with "creating and sustaining mutually satisfying exchanges of value between producer/servers and their customers. It has both a managerial orientation and an organizational/social function". Besides identifying marketing as a process, all definitions indicate some of exchange between two parties. The CIM definitions indicate that marketing aims to satisfy the needs of a customer through an offering in exchange for profits. Those of Kotler et al. (2001) and Varey (2001) explicitly mentions the creation and exchange of value as the central focus of marketing.

As earlier stated in the introduction, FDI is important and brings benefits to a country's economy. This is why countries engage in marketing through investment promotion to attract these benefits. However, it is important to understand what these countries are offering to foreign investors. This can be understood through what motivates investors to invest in another country. Dunning (1993) identifies four types of motivations; natural resources-seeking, market-seeking, efficiency-seeking and strategic asset-seeking. Natural resource motives involve seeking availability of natural resources in countries where it is in abundance, especially when same resources are not in adequate and commercial supply in the investor's home country. Market motives involves seeking new markets for goods and services in order to increase sales and revenue. Efficiency motives aims to take advantage of low production costs to produce competitive goods. Strategic-asset seeking as the name implies, involves investors seeking or acquiring assets that would give them a competitive advantage over rivals. In summary, while a country through marketing aims to satisfy the needs of investors by offering those advantages and opportunities that will make them competitive, in return the country expects to benefit from certain outcomes from the investment in the form of jobs, technology, knowledge and skills spillover, export opportunity, tax revenue and foreign exchange.

\section{Investors as Consumers and the Decision-Making Process}

Like traditional consumers seeking out products or services that will satisfy their needs, foreign investors who seek to expand internationally will likely compare and contrast several prospective investment locations against a set of criteria to determine which location is best suited in meeting their objectives. The topic of consumer behavior is extensively discussed in the field of marketing. This is because companies can improve their marketing strategies by understanding the way consumers behave in their purchase decisions (Stankevich, 2017). According Bemuse and Solomon (2016), the needs of consumers can only be satisfied to the extent by which the marketer understands those that would use the products and services they offer. To create and implement a successful marketing strategy, national governments must begin to see investors as consumers. The key to satisfying and retaining investors is by understanding their needs. This is also important in increasing the number of investors in the future. Investors needs differ depending on their motives and nature of their business activities or the industry they operate. Dunning (1993) classifies the motives as either natural resource seeking, market-seeking, efficiency seeking or strategic-seeking. It is also the case that the motives of investors are more than one (Chorell \& Nilsson, 2006) and are interconnected with each other, making it harder to identify (Anwar, Hasse, \& Rabbi, 2008).

\subsection{Decision-Making Process}

\subsubsection{Recognition of Problem}

In order to remain competitive and maximize profits, a company may decide to expand. This need motivates the investor to seek natural resources, markets, efficiency or assets that would help in achieving its objectives. Besides identifying a problem, the decision to expand may also be triggered by a potential opportunity. As summarized by Quinn (2012), the decision to invest are either directly related to an initial problem or an opportunity that instigated the decision-making process.

\subsubsection{Information Search}

Information search is required for gathering information about possible investment locations in order to make the 
right choice. According to Dean and Sharfman (1993) information gathering is important to the investment decision and the analysis of this information is key to the decision process. Through an extensive information search, the investor will have a better and more accurate perception on the environmental conditions of the location. Most importantly, information search is carried to determine which locations can satisfy the investor's needs.

\subsubsection{Evaluation of Alternatives}

After the problem has been recognized and several alternatives or options on locations have been identified from the search, the investor enters the stage of where these alternatives have to be evaluated before a decision is made. In this stage investors compare a list of several possible locations using a set of criteria already predetermined in order to decide on the best location for their investment. The investor engages in a broad attempt to identify each country's relevant characteristics such as the economic and political condition, human resources available, cost of operation and general business environment (Spar, 1998). Relevant information can be obtained from appropriate governmental economic departments, consultancy organizations, international organizations, country websites and brochures. Site or country visits can also be carried out to have a first-hand evaluation of the location. The reason for visits is to get an insider perspective on the business environment in the various locations (Spar, 1998).

\subsubsection{Investment Location Decision}

Once the investor has carried an evaluation of the different locations, a preference for a specific location is formed. After forming a preference, the investor decides to invest in the location and begins preparations.

\subsubsection{Post-Investment Behavior}

After making the investments and operating in the selected location, an investor is either satisfied or dissatisfied with the experience. This depends on if the investor is able to achieve the objectives for investments and influence of the location factors. If the investor is satisfied, a decision is made to continue operations and even reinvest and expand. Another outcome from satisfaction is a positive word of mouth through testimonials that can serve as promotion for the country. A dissatisfied investor will likely disinvest and leave the country. In addition, they can serve as a medium for a negative word of mouth.

\subsection{Investor Decision-Making Behavior}

Consumer behavior literature identifies four types of decision making; routine response behavior, extended decision-making, limited decision-making behavior and impulse behavior

In FDI decision making, investors exhibit an extended decision-making behavior as a result of the complexity and the financial commitment involved in making investment. FDI is an investment that involves a long-term relationship and lasting interests so therefore involves a lot consideration from the investor. They might not be familiar with the country or region, and besides the direct information provided investment promotion officers, a research and evaluation will be carried out. Investors will seek the opinion of advisers, specialists and even investors already operating in the country. It should be noted that FDI is usually carried by business entities known as multinational companies (MNCs), and so this is a business decision.

Investors can also exhibit a limited decision-making behavior. It happens when the investor decides to reinvest or expand its operations in the country. In this situation there is a familiarity of the country and the business environment, and so less research and evaluation are carried out before committing to more investments.

\section{Investor Targeting and Market Segmentation}

Investor targeting is another marketing tool that is applied by investment promotion agencies (IPAs) in attracting investors. Like in marketing to consumers where businesses identify those consumers groups that they can best serve their needs and will respond positively to promotional campaigns, national governments through their IPAs aim to target those investors which are likely to invest in their countries. In marketing literature, this activity is called market segmentation. Market segmentation is one of the most applied marketing strategies and was first developed by Smith (1957). According to Dolnicar, Grün, and Leisch (2018), it is one of the building blocks in strategic marketing. It is simply concerned with grouping consumers according to their needs with the aim of identifying those groups which the company's product can satisfy, and to focus the marketing efforts on them (Blythe, 2005). McDonald and Dunbar (2013) defines this process as dividing potential customers into different segments, within which they share a common level of interest in a set of needs that can be satisfied with a specific marketing proposition. As consumers have diverse needs and wants, it is impossible to customize and serve all consumers. Therefore, the use of market segmentation is very important. Also referred to as segmenting, 
targeting and positioning (STP), it is a process that helps a company effectively target consumers more efficiently and economically. As summarized by Kotler and Armstrong (2010), the marketer first identifies the target market for the product or service and groups them as segments according to their needs (Segmenting). Secondly, after an evaluation of the market segments, the most attractive markets are selected and targeted (Targeting). Finally, after the segments have been selected, the marketer positions the product in a desirable way that will appeal to needs of the target consumers through communicating and delivering the right benefits (Positioning).

In Investment promotion, investor targeting involves reaching out proactively to those investors that have been identified as desirable and likely to invest, in order to offer them a customized proposition. Meeting the need of every investor is impossible, therefore the marketing strategy is to focus the marketing efforts on those groups the government can satisfy and benefit from. Through segmentation IPAs can concentrate the limited resources on marketing efforts towards those investors that will likely respond.

\subsection{Segmenting}

Segmenting involves grouping investors according to their needs and characteristics. Segmenting foreign investors can be through grouping them by their motives and nature of their operations. This has already been discussed where it was established that there are four kinds of foreign investors as classified by Dunning (1993); natural resource-seeking, efficiency- seeking, marketing-seeking and strategic asset-seeking. This is because the nature of the business and the motives determines the location or destination of their investments. Besides identifying investors by their motives, they can be grouped by their sizes and their potential impact.

\subsection{Targeting}

After the investors have been segmented and identified according to their nature of activities, sector and motives, the country will decide and target those foreign investors best suitable in helping it achieve its economic goals and whose needs they can meet in return. It is difficult or not possible to serve all investors in the FDI market, as they are numerous and vary in their investing requirements (Trnik, 2007). Investor targeting ensures that there is an effective and efficient use in scarce resources as the country will focus its efforts on those investors that would be most beneficial to the economy. This technique will also attract a greater quantity and quality of foreign investments. Loewendahl (2001) adds that investors respond better to materials, which are relevant to them. It is suggested that when targeting a sector, the host country should identify sectors where it is best placed to attract investments (Potter \& Moore, 2000; Brand, Hill, \& Munday, 2000). The idea is to go for those investors where their needs can be satisfied better than other countries by relative of the host country's strengths. Investors usually have a list of potential locations they consider for investing in. Through targeting, a location not earlier considered can make it into an investor's list, and these investors will also have access to information that has been customized for their purpose.

\subsection{Positioning}

After identifying potential investors from the various segments, a positioning strategy for the target investor is considered. Positioning is the arrangement of a product to occupy a distinct and desirable place in the mind of the target customer in relative to other competing products. An offer is developed and positioned in the minds of the targeted investors as delivering some benefits. In practice, positioning involves the ways in which the competitive advantage of the country is built and communicated to foreign investors. This involves selecting an appropriate marketing mix for the target investor segments. The marketing mix has remained one the most relevant framework in both marketing theory and practice. The 4Ps as coined by McCarthy (1964) stands for the product, price, place and promotion. Today it is popularly known as the $7 \mathrm{ps}$ to include process, people and physical evidence due to the unique nature of services. They are a set of marketing tools that marketers use in implementing their marketing strategy (Kotler \& Armstrong, 2010). Marketing mix in the FDI context barely makes it to academic literature and is applied rarely on a national policy level. In the FDI context, the marketing mixes are those set of controllable variables that the country can use to influence the decision making of the foreign investor. Various authors (Wells \& Wint, 1990; Loewendahl, 2001) have covered promotion. Wells and Wint (1990) suggests that developing a competitive strategy for marketing activities require the manipulation of the product, price and promotion. The product represents the intrinsic advantages from the investment location. Price represents the cost to the investors from operations in the investment location. To attract investors, government offers tax incentives and holidays, lower tariffs and duty exemptions. Promotion which is marketing communication involves using several communication tools in disseminating information to prospective investors about the country as an investment location. 


\section{Concept of Investment Promotion}

The concept of investment promotion was borne out of market failures linked to information gap or asymmetry, and the need to correct them (Wells \& Wint, 1990; Loewendahl, 2001). Two approaches were identified by Trnik (2007) for attracting FDI. The first approach is the neoclassical approach based on the assumption that when government creates a friendly investment environment, foreign investors will automatically seek out opportunities for investment in that country. The problem with this approach is that not all investors are aware of the investment opportunities that exist in the country. They will rather invest where they or their competitors have invested before. The second approach which is the interventionist approach and the rationale behind investment promotion rather argues that expecting investors to locate a country for investment purposes is not enough. As earlier mentioned, the problem of information asymmetry leads to a country not attracting investment even when it has a favorable environment. It is difficult to identify where investment promotion lies in the field of marketing. While some researchers have identified similarities with industrial marketing, it can be argued that it is similar to destination marketing. I would argue that investment promotion is at an intersection between industrial marketing and destination marketing.

Investment promotion is the use of marketing activities by the government to attract foreign investors into the country. It also involves the creation of awareness about a location as an attractive destination for investment. Investment promotion activities are carried out by investment promotion agencies (IPAs) which are agencies created by the government specifically for the purpose of marketing a country to foreign investors and also encouraging investors to continue investing and expanding.

While there many activities conducted in investment promotions, these activities have been grouped into four core functions: image building, investment generation, investment facilitation and policy advocacy.

Table 1. Investment promotion functions

\begin{tabular}{|c|c|c|}
\hline Functions & Description/ Objective & Example of Activity \\
\hline Image building & $\begin{array}{l}\text { For creating awareness, and to generate positive views } \\
\text { and perception about a country as an attractive } \\
\text { investment destination }\end{array}$ & $\begin{array}{l}\text { Advertising, Website, Brochures and public } \\
\text { relations }\end{array}$ \\
\hline Investment generation & $\begin{array}{l}\text { To target specific foreign investors and to convince } \\
\text { them to locate their investment in the country }\end{array}$ & $\begin{array}{l}\text { Identification of targets, direct } \\
\text { contact, forums, seminars, etc } \\
\text { - Meetings with foreign investors } \\
\text { - Reaching-out campaigns } \\
\text { - Targeted communication and PR } \\
\text { events (sector-specific or investor-specific) }\end{array}$ \\
\hline Investment facilitation & $\begin{array}{l}\text { Assisting an investor to analyze his decision, establish a } \\
\text { business and ensure it continues to operate }\end{array}$ & $\begin{array}{l}\text { Provision of information, assistance in getting } \\
\text { approvals, assistance with sites, utilities, etc. }\end{array}$ \\
\hline Policy advocacy & $\begin{array}{l}\text { Supporting initiatives to improve the investment climate } \\
\text { and identifying private sector views. }\end{array}$ & $\begin{array}{l}\text { Surveys, participation in task forces, policy } \\
\text { proposals, lobbying }\end{array}$ \\
\hline
\end{tabular}

Source: Author's compilation based on study.

\section{Marketing Communication in Investment Promotion}

Marketing communications is an important part of a business organizations' overall marketing mission, and also a key determinant in their success or failure. This is no different from a country seeking to attract FDI. For many organizations, it represents the focal point of their marketing activities, and in some cases, both areas are synonymous. According to Schultz et al. (1993) both marketing and communications have been claimed to be virtually inseparable. This is because, whatever form of commercial transaction that a business organization is involved in (B2C or B2C), it uses some form of marketing communication to promote their product or service offering to achieve their financial goal.

In investment promotion, marketing communication plays an important role in the overall strategy. In fact, most of the marketing activities relate to marketing communications and plays a key role in IPA activities. Countries through their IPAs involve a mix of communication tools in their promotion efforts and these tools serve several functions. This includes advertising, personal selling, direct marketing, events, public relations and brochures.

\subsection{Advertising}

Advertising is the most common form of marketing communication tool. It is a form of paid non-personal communication used to promote goods, services or ideas through mass media. Countries engage in advertising of 
their country as an attractive destination for investment. Broadcast media like television is an example. Print media like magazines and newspapers are also common. According to Wells and Wint (1990), countries tend to advertise in industry or sector-specific media.

\subsection{Events}

Events are sponsored activities and programs usually by companies, and are designed to create interactions with customers. They are used to promote the brand as well products and services on offer. Events are a common way through which governments promote their countries as an attractive investment destination. Countries organize investment exhibitions, seminars, trade shows and conferences where they invite potential investors. They also attend relevant events organized by others where they can target investors and present them with investment proposals. These events are used to communicate the investment opportunities in the country to foreign investors.

\subsection{Personal Selling}

Personal selling involves a face-to-face presentation and interaction between the sellers and buyers about a product. It represents a two-way form of communication as the seller aims to persuade the buyer to purchase a product. Kotler and Keller (2016) summarizes the purpose of personal selling is to make presentations, answers questions and procure orders. Personal selling is an ever-present communication tool in promoting investments. According to Capik (2019) it is efficient one of the most commonly used tools. The nature of personal selling gives the investor an opportunity to ask questions and receive responses. It is a very key marketing communication tool and would require marketing experts and investment professionals with knowledge of the details about the investment opportunities.

\subsection{Public Relations}

Public relations involve the creation of a favorable image for an organization, both profit and non-profit in the minds of people. PR does not necessarily focus on the product in terms of for-profit activities, but rather on the company itself. The objective of PR is to influence public opinion and achieve an understanding with the audience (Todorova, 2015). According to Blythe (2005), it is concerned with the long-term reputation of the company and not a short-term marketing strategy. As Ali and Allan (2017) puts it, the work of public relations is raising the profile of an association. This is no different from the role it plays in a country's investment promotions strategy. Image building is a core function of investment promotion and public relations plays an important role in achieving the objective of creating a positive perception about a country in the minds of foreign investors. It is key that a country has a favorable image as it will make attracting investments easier. Public relations activities are not necessarily focused on the investment opportunities, they are focused on the whole country as a whole. Event publicity, press relations and lobbying are some of the important tools of public relations (Capik, 2019).

\subsection{Online Marketing}

The internet has become a trend that is unstoppable and irrevocable. Therefore, it is imperative for companies to have an online presence and engage in online marketing. Online marketing is simply the promotion of products and services on the internet. It uses the internet to deliver promotional messages to a target audience. It includes search engine marketing (SEM), email marketing which are important for investment promotion. For example, SEM helps to improve the visibility of the IPA website of the country. Websites are very important in the information search stage in an investor decision making. Apart from being a source of information, it is a kind of online advertisement and brochure. A website serves as the first point of contact for the investor with the IPA (Ortega \& Griffin, 2009) and acts like an information portal which should be up-to-date and reliable.

\subsection{Brochure}

Brochures are common in investment promotion. They are informative paper documents used for promotion. They are used to present information about a country and its economic environment. Most importantly, it informs the investor on the investment opportunities and the benefits. Brochures provides an availability for more information than other print forms like magazines and newspapers used for adverts. They can be used in combination with other marketing communication tools like events, personal selling, online marketing (e-brochure)

\section{Conclusion}

This paper introduced investment promotion, a concept that involves the use of marketing in attracting FDI. It is not a new concept but hardly makes it to academic literature. Marketing has mainly been the purview of business 
organizations, but with the increasing benefits of FDI to a country and the fierce competition among countries to attract FDI, the creation of investment promotion agencies, a government institution responsible for marketing a country as an attractive investment destination is no longer optional but a necessity.

\section{References}

Aitken, B. J., \& Harrison, A. E. (1999). Do domestic firms benefit from direct foreign investment? Evidence from Venezuela. American Economic Review, 89(3), 605-618. https://doi.org/10.1257/aer.89.3.605

Ali, N. N. H., \& Allan, M. (2017). The Role of Integrated Marketing Communications in Increasing the Efficiency of Internet-based Marketing among Jordanian Consumers. International Journal of Marketing Studies, 9(4), 97-110. https://doi.org/10.5539/ijms.v9n4p97

Anwar, A. I., Hasse, R., \& Rabbi, F. (2008). Location determinants of Indian outward foreign direct investment: How multinationals choose their investment destinations?

Bamossy, G. J., \& Solomon, M. R. (2016). Consumer behaviour: A European perspective (6th ed.). Pearson Education.

Blythe, J. (2005). Essentials of marketing (3rd ed.). Pearson Education.

Brand, S., Hill, S., \& Munday, M. (2000). Assessing the impacts of foreign manufacturing on regional economies: the cases of Wales, Scotland and the West Midlands. Regional Studies, 34(4), 343-355. https://doi.org/10.1080/00343400050078123

Capik, P. (2019). Foreign Investment Promotion: Governance and Implementation in Central-Eastern European Regions. Palgrave Macmillan (part of Springer Nature). https://doi.org/10.1007/978-3-030-13658-1

Chorell, H., \& Nilsson, E. (2006). Chinese FDI in the Oil Sector: Can they be explained by the prevalent theory on FDI? Master thesis, Nationalekonomiska institutionen. Retrieved from http://www.diva-portal.org

Dean Jr, J. W., \& Sharfman, M. P. (1993). Procedural rationality in the strategic decision-making process. Journal of Management Studies, 30(4), 587-610. https://doi.org/10.1111/j.1467-6486.1993.tb00317.x

Dolnicar, S., Grün, B., \& Leisch, F. (2018). Market Segmentation Analysis. In Market Segmentation Analysis (pp. 11-22). Singapore: Springer. https://doi.org/10.1007/978-981-10-8818-6_2

Dunning, J. H. (1993). Multinational Enterprises and the Global Economy. Wokinghan England, Addison-Wesley.

Harding, T., \& Javorcik, B. S. (2011). Roll out the red carpet and they will come: Investment promotion and FDI inflows. The Economic Journal, 121(557), 1445-1476. https://doi.org/10.1111/j.1468-0297.2011.02454.x

Hill, C. (2000). International Business - Competing in the Global Marketplace. University of Washington: Irwin McGraw-Hill.

Kotler, P., \& Armstrong, G. (2010). Principles of Marketing (13th Global ed.). Boston: Pearson Education, Inc.

Kotler, P., Armstrong, G., Saunders, J., \& Wong, V. (2001). Principles of marketing (3rd European ed.). Prentice Hall, Harlow.

Kotler, P., \& Keller, K. L. (2016). A framework for Marketing Management (6th ed.). Pearson Education.

Loewendahl, H. (2001). A framework for FDI promotion. Transnational Corporations, 10(1), 1-42.

McCarthy, J. (1964). The concept of the marketing mix. Journal of Advertising Research, June, 2-7.

McDonald, M., \& Dunbar, I. (2013). Market segmentation: How to do it and how to profit from it (4th ed.). John Wiley \& Sons. https://doi.org/10.1002/9781119207863

Ortega, C., \& Griffin, C. (2009). Investment promotion essentials: What sets the world's best investment facilitators apart from the rest?

Potter, J., \& Moore, B. (2000). UK enterprise zones and the attraction of inward investment. Urban Studies, 37(8), 1279-1311. https://doi.org/10.1080/00420980020080141

Quinn, F. (2012). The Foreign Direct Investment Location Decision: A Contingency Model of the Foreign Direct Investment Location Decision-making Process. Doctoral dissertation. Retrieved from https://ses.library.usyd.edu.au

Schultz, D. E., Tannenbaum, S., \& Lauterborn, R. (1993). The New Marketing Paradigm: Integrated Marketing Communications. Illinois: NTC Business Books. 
Smith, W. R. (1957). Product differentiation and market segmentation as alternative marketing strategies. Journal of Marketing, 21(1), 3-8. https://doi.org/10.2307/1247695

Spar, D. (1998). Attracting high technology investment: Intel's Costa Rican plant. The World Bank. https://doi.org/10.1596/0-8213-4218-5

Stankevich, A. (2017). Explaining the consumer decision-making process: Critical Literature review. Journal of $\begin{array}{llll}\text { International Business Research and } & \text { Marketing, }\end{array}$ https://doi.org/10.18775/jibrm.1849-8558.2015.26.3001

Todorova, G. (2015). Marketing communication mix. Trakia Journal of Sciences, 13(1), 368-374. https://doi.org/10.15547/tjs.2015.s.01.063

Trník, M. (2007). The role of investment promotion agencies at attracting foreign direct investment and their impact on economic development in Central Europe (The Czech Republic and Slovakia in comparative perspective). Doctoral dissertation. Retrieved from http://www.diplomovka.sme.sk

Varey, R. J. (2001). Marketing Communication: A Critical Introduction. https://doi.org/10.4324/9780203466919

Wells, L. T. J., \& Wint, A. G. (1990). Marketing a country: promotion as a tool for attracting foreign investment. The World Bank. https://doi.org/10.1596/0-8213-4659-8

World Bank Group. (2014). A Guide to Investor Targeting in Agribusiness. Washington, DC. (C) World Bank. Retrieved from https://openknowledge.worldbank.org/handle/10986/21720 License: CC BY 3.0 IGO

\section{Copyrights}

Copyright for this article is retained by the author, with first publication rights granted to the journal.

This is an open-access article distributed under the terms and conditions of the Creative Commons Attribution license (http://creativecommons.org/licenses/by/4.0/). 